\title{
Inhalt
}

Vorwort zu NK 5/1 - VII

Hinweise zur Benutzung — XI

Siglenverzeichnis - XIII

Editorische Zeichen — XVII

\section{Jenseits von Gut und Böse}

I Überblickskommentar - 3

1 Entstehungsgeschichte und Textgeschichte - 3

2 N.s werkspezifische Äußerungen — 8

3 Quellen - 17

4 Konzeption und Struktur $-\mathbf{1 9}$

5 Stellenwert von Jenseits von Gut und Böse in N.s Schaffen - 27

6 Zur Wirkungsgeschichte $-\mathbf{3 0}$

II Stellenkommentar -41

Der Titel - 41

Vorrede. -47

Erstes Hauptstück: von den Vorurtheilen der Philosophen. - 74

Zweites Hauptstück: der freie Geist. -214

Drittes Hauptstück: das religiöse Wesen. — 311

Viertes Hauptstück: Sprüche und Zwischenspiele. - 381

Fünftes Hauptstück: zur Naturgeschichte der Moral. - 493

Sechstes Hauptstück: wir Gelehrten. - $\mathbf{5 5 6}$

Siebentes Hauptstück: unsere Tugenden. - 605

Achtes Hauptstück: Völker und Vaterländer. — 672

Neuntes Hauptstück: was ist vornehm? - 728

Aus hohen Bergen. Nachgesang. — 811

Literaturverzeichnis -817

Sach- und Begriffsregister $-\mathbf{8 9 5}$

Personenregister -923 
